\title{
An Exploratory Study of the Factors Affecting Labor-Management Relations in the Context of Employee Satisfaction within Garments Industry of Bangladesh
}

\author{
Mohammed S. Chowdhury (Corresponding author) \\ Department of Business and Accounting, Touro College, New York, USA \\ E-mail: Mohammed.chowdhury@touro.edu or mchowdr@yahoo.com
}

Md. Nurul Amin

Department of Accounting, West Virginia University Tech, Beckley, WV, USA

E-mail: Md.Amin@mail.wvu.edu

Zahurul Alam

Department of Management, Chittagong University, Bangladesh

E-mail: zahurul_CU@yahoo.com

Received: January 30, 2019 Accepted: February 15, 2019 Published: March 24, 2019

doi:10.5296/ber.v9i1.14540

URL: https://doi.org/10.5296/ber.v9i1.14540

\begin{abstract}
The study examined the factors that affected Labor-Management Relations in the context of employees' satisfaction in Garments Industry of Bangladesh. The data for the study were collected from both primary and secondary sources. Primary sources relied on interview method with the help of a structured questionnaire for self-guidance. All hypotheses were tested using regression analysis and Pearson correlations controlling for background variables of gender, marital status, and age. The study revealed that all dimensions of labor-management relations were positively and significantly correlated to employee satisfaction and overall labor-management relations. Implications, limitations, and directions for further research were discussed.
\end{abstract}


Keywords: Labor-management relations, Ready-made garments, Workers' satisfaction, Industrial dispute, Transparency

\section{Introduction}

The Labor-Management Relations (LMR) refers to interactions between employees and their employers. The main objective of LMR is to prevent industrial disputes and strengthen harmonious relations between employees and the management.

Ready-made Garments (RMG) Industry of Bangladeshis labor intensive. It started its journey in the 1970s with small factories in residential and commercial buildings and has now become a huge industry employing some four million people, predominantly women (80 percent) and the industry contributes to $81 \%$ of the country's export earnings and $13 \%$ of GDP (BGMEA, 2017).

Despite this bright prospect, the working conditions in these factories have long been criticized as being deplorable for lack of enough light, space, and purified drinking water. Health and safety hazards of these factories have also been depressing. Moreover, LMR and the trade union movement are weak in RMG industry of Bangladesh (Mohiuddin, 2014). While trade unions exist, they are ineffective in the application of their objectives (ILO, 2016). The objective of this paper is, therefore, to identify the factors that affect labor-management relations and examine their relationship with overall employees' satisfaction.

\subsection{Justification of this Study}

The study is justified for a number of reasons. First, building and sustaining a productive labor-management relation is critical for a nation to accomplish goals such as higher per capita GDP, better literacy, high quality physical environment and long life expectancy, Second, it is a widely held belief in the academic and industrial world that the absence of internationally accepted and well- functioning labor laws in a country can cripple not only the industry but the entire economy, resulting in labor unrest, decline in employee morale, disruptive behavior of the employees, decline in foreign and domestic investment, deterioration in law and order, and political chaos. Third, RMG industry in Bangladesh has, unfortunately, seen a steady increase in workplace accidents and labor unrest. Therefore, there is a continuing need to improve labor standards in this country that lacks internationally accepted and well -functioning labor laws and processes (ILO, 2013). All these warrant a dynamic approach to tackle them for maintaining peaceful labor-management relations.

\subsection{Objectives of the Study}

a. To examine the fundamental problems that still exist as impediments to fostering a sound labor-management relation.

b. To examine the labor-management relations factors that cause employees' satisfaction.

Unless we address the issues of LMR, satisfactory Industrial Relations that can yield higher productivity and higher standard of living for the garment workers cannot be achieved. We 
argue that there is a lack of adequate research in this field in Bangladesh. Our argument is based on our information from experts, colleagues, intellectuals, political leaders and entrepreneurs in this industry. The study, therefore, constitutes an aid to the policy makers, researchers, and the government for improving the various aspects of LMR of RMG sector of Bangladesh.

\section{Related Literature}

LMR refers to managing employee relationship and developing psychological contract (Armstrong, 2010). A psychological contract represents the mutual benefits, perceptions, informal and formal obligations between the employees and the management. This employment relationship is a mutual, voluntary agreement between employers and employees. The employee agrees to work and the employer agrees to pay in exchange for this work. The relationship is voluntary in the sense that no employer can force the employee to work.

Dicker, L (2003) defines the concept of labor-management relations (employer-employee relations) as a function of work and employee practices and thus can be linked to performance of the organization and the employees' satisfactions. In this LMR there will always be actual and potential conflict between the employers and the employees but simultaneously there will also be shared interests (Thompson, 2011). Many employees reported the absence of shared interests between the employers and the employees during our interview with the employees.

In the LMR process trade unionism is the core of industrial relations as it seeks to remove the power imbalance between the employers and the workers. Trade unions are born out of the necessity of working class people to protect their rights and privileges as well as to defend themselves against lay-offs, injustices, and exploitation by their employers. Thus, trade unions provide a platform for workers' collective action and constitute an integral part of the relationship between employers and the employed. Unfortunately, industrial peace and relations have remained affected hampering the productivity of the workers and the nation as a whole whereas competitive compensation, good working environments, effective management and supervision, fair and responsive treatment of workers all act as antidotes to unionization efforts (Mathis and Jackson, 2011)

According to Wilkinson (1999) small firms in this industry are dictatorially run by the management with employees suffering poor conditions, inadequate safety conditions, and having little involvement in running the business, poor working environments are an everyday problem of RMG workers. Other issues that workers face are workplace safety, working hours, wage, job security, gender equality, child labor and so and so forth. In their study, Ahmed et al (2013) cited pegging long hours and sudden layoffs as the main factor of labor unrest. Other factors that this study cited were lack of minimum facilities like canteens, prayer rooms, washrooms, toilets, and child -care.

Only few RMG companies provide housing facilities for their workers; others are forced to live nearby impoverished rental houses in filthy and unhealthy conditions, resulting in labor-unrest and disturbing the production process. 
Bhuyan (2013) reported workers demand for unpaid wages and weekly holiday as the prime causes of labor unrest. Delayed payment and lack of prior notification for delay, unhealthy work environment, and lack of bonus packages are other causes of labor unrest as reported by managers of RMG factories. Discrimination, especially in terms of wage level and access to higher paid positions, has been cited as a source of job dissatisfaction and labor unrest (Ahmed and Nathan, 2014). If the workers cannot fulfill the lower order needs as espoused by Maslow (1943), they become demotivating and unrest grows in them.

Maslow's (1943) Hierarchy of Needs has often been represented as an important tool in explaining labor-management relations in hierarchical pyramid with five levels. The first four levels are considered deficiency or deprivation needs ("D-needs") in that their lack of satisfaction causes a deficiency that becomes harmful in the path to improve their productivity.

- Self-actualization - includes morality, involvement, creativity, problem solving, etc.

- Esteem - includes confidence, self-esteem, achievement, respect, trust

- Belongingness - includes love, friendship, intimacy, family, etc.

- Safety - includes security of environment, employment, resources, health, property, etc.

- Physiological - includes air, food, water, sex, sleep, other factors towards homeostasis, etc.

With Maslow's theory employees emphasize on lower order-needs of physiology and security (food, shelter, and safe environment). Once these needs are met, the employees will want to have their social needs (belongingness). Open managerial communication is an important component of meeting employees' social needs. Employees who are kept in the dark about operational matters and the future plan of the organizations feel like they are organizational outsiders. Workers' next higher needs are esteem needs and these are tied to an employee's image of himself/herself and his/her desire for the respect and recognition of others. Other tools for addressing the esteem needs of the employees include job training, job enrichment, employee participation in decision making on operational matters, job perks, meaningful job title etc. Finally, for meeting the needs of self-actualization, the employees will be interested in growth and individual development.

The concept of employee voice is also an important factor. Employee voice is expressed in terms of participation in which employees are playing a greater part in decision making process and involvement in which managers allow employees to discuss with the issues that affect them. This concept is not well understood by both the management and employees in Bangladesh. This is because of poor literacy level of workers. They are not well communicated about their rights and obligations. Good communication with the employees is vital for building labor-management relationship. In one direction good communication enables organizations to inform employees about matters that will interest them. In another direction, the organizations provide for upward communication by giving employees a voice.

Since 2012, agitations among RMG workers have flared in many RMG factories in Bangladesh. These agitations are mainly due to lack of labor rights, poor working conditions, and high level of violence against women. (Blumer, 2016). Conflicts between workers and 
factory owners are gradually increasing and incidences of violence are on the rise resulting in the lives of the workers and damage of the properties in millions of U.S. \$ (dollars). The collapse of Rana Plaza building in 2013 that was housing few factories in Savar, an industrial city near Dhaka, killed more than 1100 workers and injured almost 2500 workers. This incident led to the severe unrest throughout the country resulting in rioting, looting, damaging vehicles, commercial buildings and hundreds of garment factories (The New York Times, 2012). Irony was that Rana Plaza building was over-loaded with machineries and hundreds (four to five) people working in each of the five floors of the building used as garments factories with a space of only 6,000 square feet in each level (BGMEA, 2015)

Prior to the Rana Plaza collapse, several incidents of factory collapse and violence took place taking away the lives of many hundred RMG workers. One such incident occurred in Tazneen Fashions at the outskirt of Dhaka, which was engulfed with fire in 2012. That incident killed more than hundred workers.

All the above incidents and chaotic labor-management relations along with the low productivity of labor are breeding fears and distrust in foreign investment in Bangladesh. The foreign investors are no more considering Bangladesh as safe haven for their investment and becoming skeptical of accepting the country's factor advantage of cheap labor as cheap production base.

Labor indiscipline, politicization of labor union, formation of labor organizations by the government and political parties, government intervention in wage determination, low labor productivity, lack of training in labor-management relation, failure to meet the deprivation needs of the workers have been the factors that constraint labor-management relations in RMG sector of Bangladesh.

It is, therefore, time to grapple with certain of these fundamental problems that still exist as impediments to fostering a sound labor-management relation. Unless this is attempted, satisfactory Industrial Relations that can yield higher productivity and higher standard of living for the garment workers cannot be achieved.

\section{Theoretical Model and Hypotheses}

Based on above literature we have presented the factors that affect labor-management relations. Prior studies reveal that the LMR in RMG is a function of multiple indicators. In this study we have identified five dimensions of factors affecting LMR, as depicted in our model below:

$\mathrm{LMR}=\mathrm{f}(\mathrm{WW}, \mathrm{WS}, \mathrm{CD}, \mathrm{LLR}, \mathrm{DTG})$

Where WW $=$ Wages and Welfare; WS = Works Situations; $\mathrm{CD}=$ Career

Development; LLR = Labor Laws and Regulations; DTG = Democratic and Transparent Government. 
Table 1. Dimensions of LMR attributes and their operational definitions

\begin{tabular}{|l|l|}
\hline Factor name & Variable name \\
\hline $\begin{array}{l}\text { F1: Wages and Welfare } \\
\text { (10 items) }\end{array}$ & $\begin{array}{l}\text { Wages pay, Bonus pay, Overtime pay, Wages increase, Reward } \\
\text { distribution system, Security of pay, Medical leave, Maternity } \\
\text { leave, Health care facilities, elimination of child labor }\end{array}$ \\
\hline $\begin{array}{l}\text { F2: Working Situations } \\
\text { (5 items) }\end{array}$ & $\begin{array}{l}\text { Physical Job Stress, Safety problem, Working hours, Relationship } \\
\text { with owner-managers, Sudden shut down of factory. }\end{array}$ \\
\hline $\begin{array}{l}\text { F3: Career Development } \\
\text { (4 items) }\end{array}$ & $\begin{array}{l}\text { Promotion opportunity, Job security, Confidence in future } \\
\text { prospect of the enterprise, Training }\end{array}$ \\
\hline $\begin{array}{l}\text { F4: Labor laws } \\
\text { and regulations (4 items) }\end{array}$ & $\begin{array}{l}\text { Enforcement of labor contracts, Workers knowledge of labor laws, Workers' } \\
\text { participation in rules and regulations, Coercive role of law enforcing agencies. }\end{array}$ \\
\hline $\begin{array}{l}\text { F5: Democratic and } \\
\text { Transparent Govt. } \\
\text { [Government (4)] }\end{array}$ & $\begin{array}{l}\text { Absence of democracy, Absence of transparency, Politicization } \\
\text { of labor fronts, Government's reluctance to accept labor rights. }\end{array}$ \\
\hline
\end{tabular}

Source: author

We have deduced a model from table 1 (see figure 1). The model is based on the assumption that maintaining and managing labor-management relations and employees' satisfaction depend on addressing the issues depicted in our model.

The Theoretical Model is pictured in Figure 1 below:

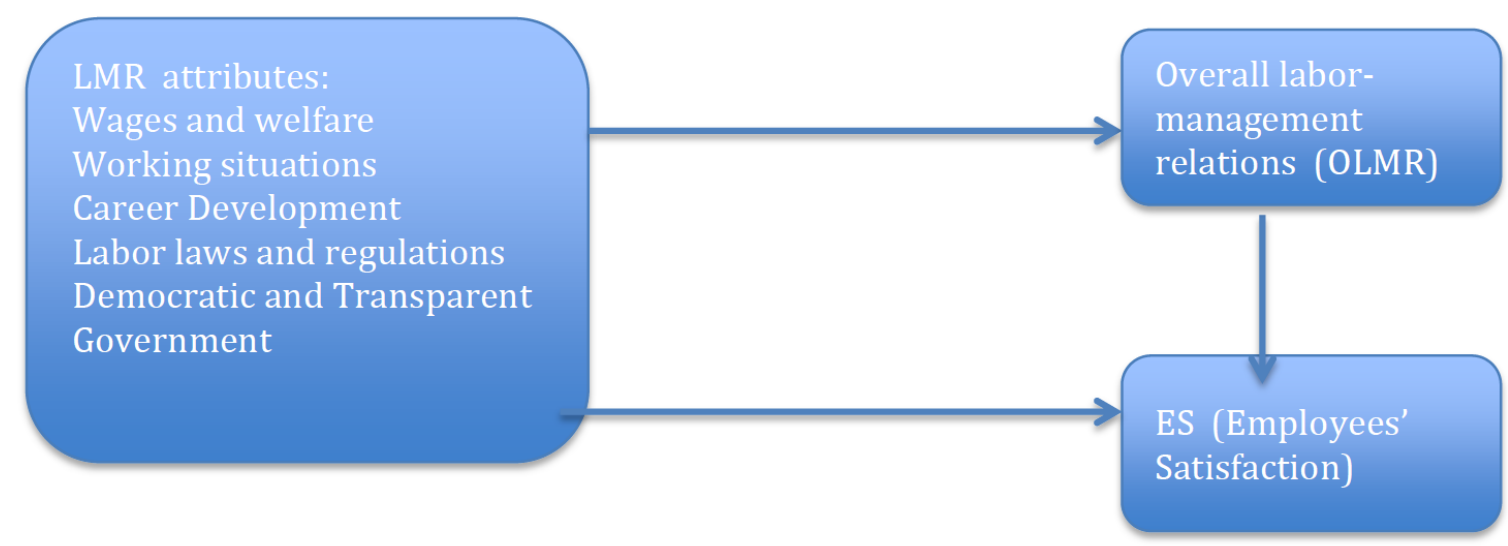

Figure 1. Theoretical Model

Source: author

The model exhibits two features:

a. LMR attributes affect both overall LMR and employees' satisfaction.

b. The employees' satisfaction is also affected by overall LMR. 


\subsection{Research Questions}

- Is there any significant relationship of LMR attributes (wages and welfare, employees" satisfaction, career development, labor laws and regulations, democratic and transparent government) with LMR?

- Is there any significant relationship of all LMR attributes with employee satisfaction?

- Are employees satisfied with overall LMR?

\subsection{Hypotheses}

- H1: There is a significant relationship of LMR attributes (wages and welfare, work situations, career development, labor laws and regulations, and democratic and transparent government) with overall LMR.

- H2: There is a significant relationship of all five LMR attributes with employees' satisfaction.

- H3: There is a significant relationship of overall LMR with employees' satisfaction (ES)

\section{Materials and Methods}

\subsection{Survey Instrument}

The data for the study have been collected from both primary and secondary sources. Primary sources relied on interview method with the help of a structured questionnaire for self-guidance. Secondary data came from a number of literature, newspapers, books, and articles in the journals related to the field. We also used information from other sources (unions, labors, NGOs, labor right activists and researchers). We selected 20 garments exporting factories since we do not know how may factories Bangladesh has throughout the country. These factories were chosen from Chittagong area since Chittagong is the commercial hub of the country and gateway to Bangladesh.

We used non-probability sample procedure since we do not know how many employees each and every factory had since these companies were private companies and were not willing to provide information of the exact number of employees working for their enterprises. This is in consonance with several studies (Sekeran, 1992; Cooper and Schindler, 2003). We approached 195 employees working in different factories under study but only 99 employees participated (response rate 55 percent). The variables in the survey instrument were derived from exploratory research and the relevant theoretical and empirical literature. We have outlined 27 variables in five categories (see table1), which we have included in our survey. We anchored Five- point Likert-Scale from strongly disagree (1) to strongly agree (5) to measure labor-management relations. The first category comprised a set of 10 items relating to wages and welfare of the workers. A typical item was: The wages of workers in this industry is satisfactory. The second category consisted of five items relating to working situations. One typical item was: The workers do feel safe in this industry during their work time. The third category consisted of four items of career development. One such item was: The job of the workers is secured in this industry. The fourth category consisted of four items relating to labor laws and regulations. One such item was: labor contracts are enforced in this 
industry. The fifth and final category consisted of four items comprising democratic and transparent government. One such typical item was: Absence of democratic government in the country hinders labor-management relations.

The respondents were also asked to rate the "overall LMR dimensions quality of RMG industry using a 5-point semantic differential scale. Scores range from very low (1) to very high (5) to confirm all five categories of labor-management relations in determining employees' satisfaction with over all LMR (OLMR). In this study we measured employees' satisfaction by a single direct question as "Overall how satisfied are you with the labor-management relations in the RMG industry of Bangladesh. This is in consonant with several studies (e.g., Westbrook, 1980; Oliver, 1980, Montinaro and Chirico, 2006). They all indicated that single item rating scales were common among researchers in measuring satisfaction.

\section{Reliability Analysis}

The reliability analysis of all five dimensions is depicted in table 2 below.

Table 2. Reliability Analysis

\begin{tabular}{|l|l|}
\hline LMR Dimensions & Cronbach's Alpha \\
\hline Wages and Welfare (WW) & 0.92 \\
\hline Working situations (WSt) & 0.88 \\
\hline Career Development (CD) & 0.86 \\
\hline Labor laws and Regulations (LLR) & 0.81 \\
\hline Democratic and Transparent Govt. (DTG) & 0.78 \\
\hline Overall LMR & 0.89 \\
\hline
\end{tabular}

The values of Cronbach's alpha are greater than 0.6 for each variable and hence considered acceptable (Nunally, 1978). Cronbach's alpha for all constructs ranged from .78 to .92, as depicted in table 2. The Kaiser-Meyer-Ohlin Sampling Adequacy coefficient was .90, indicating strong internal consistency. We conclude that the research instrument used in the study is valid and reliable.

We approached each employee and proposed to him or her to fill up the questionnaire. Interviewers approached employees at cafes, shops, and other locales where employees commonly gather after work. The names of the factories involved in this study are not published because of the sensitive nature of the results and of the business relationships involved.

\subsection{Data Analysis}

In order to establish relationships between LMR attributes and workers' satisfaction we employed correlation and regression analyses. Hypothesis testing was done to analyze direct effects of independent variables on LMR controlling for demographic variables. The regression analysis was employed to look at the effects of LMR dimensions on workers' satisfaction and overall labor-management relations. The regression models are: 


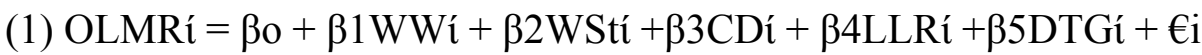

(2) WSí = $\beta o+\beta 1 \mathrm{WWí}+\beta 2 \mathrm{WSí}+\beta 3 \mathrm{CDí}+\beta 4 \mathrm{LRí}+\beta 5 \mathrm{DTG}$ + $€ \mathrm{I}$

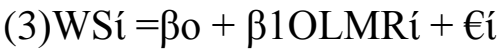

Note: Wsti =working' situations; CD =Career Development; LLR=Labor laws and regulations; $\mathrm{DTG}=$ Democratic and transparent government and $i$ for worker $i$. That is equation (1) corresponds to $\mathrm{H} 1$, equation (2) to $\mathrm{H} 2$ and equation (3) to $\mathrm{H} 3$.

\subsection{Results}

The results in table 4 depict that variables related to all five factors (see table1) are highly perceived as LMR satisfaction growth indicators. A careful examination of the factors listed in table reveal that all factors are perceived as important factors affecting the growth and development of LMR in RMG industry in Bangladesh.

Table 3. Descriptive statistics of al 27 variables of five dimensions of LMR (see table 1)

\begin{tabular}{|l|l|l|l|l|l|}
\hline Variable name & Mean & SD & Variable name & Mean & SD \\
\hline X1 wages pay & 4.88 & 0.33 & X14relationship with managers & 4.75 & 0.43 \\
\hline X2overtime pay & 4.45 & 0.66 & X15 sudden factory shut-down & 4.88 & 0.33 \\
\hline X3Bonus pay & 4.63 & 0.48 & X16promotion opportunity & 4.25 & 0.92 \\
\hline X4 reward system & 4.25 & 1.09 & X17 Job security & 4.88 & 0.33 \\
\hline X5 security of pay & 4.88 & 0.33 & X18 Training & 4.4 & 1.20 \\
\hline X6 medical leave & 4.6 & 0.8 & X19 confidence about the future of enterprise & 4.18 & 0.72 \\
\hline X7 maternity leave & 4.55 & 0.66 & X20 enforcement of labor contracts & 4.08 & 1.11 \\
\hline X8 health care facility & 4.5 & 0.87 & X21 Workers' knowledge of labor laws & 5 & 0.65 \\
\hline $\begin{array}{l}\text { X9 elimination of } \\
\text { child labor }\end{array}$ & 4.63 & 0.48 & X22workers' participation in rules and regulations & 4.88 & 0.33 \\
\hline X10 wages increase & 4.90 & 0.34 & X23 coercive role of law enforcing agencies & 3.83 & 0.69 \\
\hline X11physical job stress & 4.67 & 0.47 & X24 absence of democracy & 5 & 0.73 \\
\hline X12 safety problems & 5 & 0 & X25 absence of transparency & 4.5 & 1.00 \\
\hline X13 Working hours & 4.75 & 0.66 & X26politicization of labor fronts & 4.29 & 0.70 \\
\hline & & & $\begin{array}{l}\text { X27 reluctance of government to } \\
\text { accept labor rights }\end{array}$ & 4.88 & 0.33 \\
& & & & & \\
\hline
\end{tabular}

\subsection{Correlation and Regression Analysis}

All the variables in above table are deduced from five dimensions of LMR. We constructed a correlation matrix to see if there are significant correlation between the dependent and independent variables. All independent variables have been grouped into five dimensions for simplicity and clarity of the correlation study with the dependent variables overall LMR (OLMR) and employees' satisfaction (ES).Table 4 reports the correlation matrix. All LMR dimensions are positively and significantly related to employees' satisfaction and overall LMR. 
Table 4. Inter-correlation among dependent and independent variables

\begin{tabular}{|l|l|l|l|l|l|l|l|}
\hline & ES & OLMR & WW & WSt & CD & LLR & DTG \\
\hline ES & 1 & $0.859^{* *}$ & $0.556^{* *}$ & $0.756^{* *}$ & $0.566^{* *}$ & $0.436^{* *}$ & $0.768^{* *}$ \\
\hline OMLR & & 1 & $0.867^{* *}$ & $0.767^{* *}$ & $0.461^{* *}$ & $0.445^{* *}$ & $0.778^{* *}$ \\
\hline WW & & & 1 & $0.854^{* *}$ & $0.361^{* *}$ & $0.522^{* *}$ & $0.648^{* *}$ \\
\hline WSt & & & & 1 & $0.434^{* *}$ & $0 . .697^{* *}$ & $0.6 .67 * *$ \\
\hline CD & & & & & 1 & $0.407^{* *}$ & $0.489 * *$ \\
\hline LLR & & & & & & 1 & $0.424 * *$ \\
\hline DTG & & & & & & & 1 \\
\hline
\end{tabular}

The correlation is significant at 0.01 level (1-tailed).

Note: ES is the abbreviation for Employees' Satisfaction, WSt for work situations, OLMR for over all labor-management relations, WW for wages and welfare, CD for career development, LLR for labor laws and regulations, DTG for democratic and transparent government.

\section{Test for Multicollinearity}

Table 5indicates that tolerance values for LMR dimensions are above 0.10. Likewise, all of the variance inflation factor (VIF) values are less than 10, thus confirming the multicollinearity is not a concern (Burns and Busch, 2007).

Table 5. Multicollinearity Statistics

\begin{tabular}{|l|l|l|}
\hline Independent variables & Tolerance & VIF \\
\hline WW(Wages and Welfare) & 0.976 & 1.09 \\
\hline WSt (Workers' situations) & 0.776 & 1.87 \\
\hline CD (Career Development) & 0.459 & 2.06 \\
\hline LLR(Labor laws and regulations) & 0.799 & 1.81 \\
\hline DTG (Democratic and transparent Government) & 0.765 & 1.36 \\
\hline
\end{tabular}

\section{Regression Analysis}

The results of equation (1) are reported in table 6. All LMR dimensions have influenced OLMR (over all labor-management relations), as evidenced by large coefficients and $\mathrm{t}$ statistics. The $F$-value is 26.69 and $P$ value is 0.000 , which is significant at $5 \%$ level. $\mathrm{H} 1$ is accepted. From the Adjusted R-squared value $30.9 \%$ of the changes in dependent variable OLMR are explained by the independent variables. 
Table 6. Regression of OLMR on LMR dimensions

\begin{tabular}{|l|l|l|l|}
\hline Independent variables & $\beta$ & T-stat & p-value \\
\hline Constant & 1.89 & 11.9 & 0.000 \\
\hline Wages and Welfare & 0.497 & 3.49 & 0.000 \\
\hline Working situations & 0379 & 2.78 & 0.000 \\
\hline Career development & 0.238 & 2.08 & 0.000 \\
\hline Labor laws \& regulations & 0.378 & 2.60 & 0.000 \\
\hline Democratic and transparent government & 0.702 & 2.39 & 0.000 \\
\hline Adjusted R Square 30.9: F-Value 22.8; Significance 0.00 \\
\hline
\end{tabular}

Similarly, we evaluate $\mathrm{H} 2$ by estimating equation (2). All LMR dimensions have influenced workers satisfaction, as evidenced by large coefficient estimates and T-statistics. F-value is 19.8. p-value is 0.000, which is significant at 5\% level (H2 accepted). The Adjusted R-Squared indicated 27.8 percent of the changes in the dependent variable ES (employees' satisfaction) are explained by predictor variables (see table8)

Table 7. Regression of ES on LMR dimensions

\begin{tabular}{|l|l|l|l|}
\hline Independent variables & $\beta$ & T-stat & $p$-value \\
\hline Constant & 2.49 & 13.6 & 0.000 \\
\hline Wages and Welfare & 3.05 & 4.07 & 0.000 \\
\hline Working situations & 0.216 & 5.08 & 0.000 \\
\hline Career development & 0.289 & 2.83 & 0.000 \\
\hline Labor laws \& regulations & 0.189 & 3.33 & 0.000 \\
\hline Democratic and transparent government & 0.269 & 6.06 & 0.000 \\
\hline Adjusted R-Squared 27.8; F-value 19.8; Significance 0.000 \\
\hline
\end{tabular}

We evaluate H3 by estimating equation (3). OLMR has a strong impact on ES (employees' satisfactions), as evidenced by large coefficient estimates, T-statistics, supporting H3. The Adjusted R-Squared implies that 33.8 percent of the changes in the dependent variable are explained by the predictor variable OLMR. See table 8

Table 8. Regression of ES on OLMR

\begin{tabular}{|l|l|l|l|}
\hline Independent variables & $\mathrm{B}$ & T-stat & $P$-value \\
\hline Constant & 0.889 & 9.86 & 0.000 \\
\hline OLMR & 0.989 & 17.30 & 0.000 \\
\hline Adjusted R-Squared 33.8; F-value 23.76; P-value 0.000 \\
\hline
\end{tabular}

\section{Conclusions and Implications}

The study reveals that all LMR dimensions are positively and significantly related to employees' satisfaction and overall LMR, as is evidenced from table 4. All three hypotheses are accepted ( $\mathrm{P}$-value 00) All LMR dimensions are positively and significantly related to employees' satisfaction and overall LMR (OLMR). This result is consistent with several studies (Odhong and Omolo, 2014; Ferdous, 2015). This study also shows that knowing 
about employees' needs and improving LMR quality in terms of employees' needs are very important in fostering LMR in RMG industry of Bangladesh. It is, therefore essential for Bangladesh Garments industry to explore the causes of dissatisfaction of garments workers, pay close attention to their needs (current and potential) and do whatever is necessary to institute and establish a lasting LMR for greater productivity of the industry.

This study implies that to improve employees' satisfaction decision makers, policy makers, and government should address and improve the quality of all dimensions of LMR. This study further implies that proper addressing the LMR issues that meet the workers' needs, improve working' situations, improving job skills through training for workers, guarantees security of jobs, prevent politicization of labor organizations can reduce labor tensions and unrest in this vibrant industry. Knowing what satisfies employees and incorporating this knowledge into LMR system will help the industry administration identify the workers' needs, recruit, employ, train and retain a productive workforce. An effective LMR is the key to the success of this industry.

\section{Limitations and Further Research Directions}

The study is not without limitations. One relates to data collection. The researchers encountered several difficulties in collecting the survey data. Future surveys should take these issues into account. Many of the workers approached by the interviewers, in particular female workers, were reluctant to participate in the survey. Commonly reported difficulties included time pressures related to running households, and reluctance to spend limited free time discussing their work issues.

The second limitation is that this study did not take into account the factors related to age, gender, and education of the respondents to the survey. Further research may be directed toward this end.

The third relates to the characteristics of the respondents since different characteristics of each respondent may give a different outcome of employees' satisfaction. It is, therefore, very important to investigate these and other factors and to conduct in-depth interviews involving a higher number of respondents for having a more relevant workers satisfaction measurement. One can also examine the LMR factors based on the employees' perceptions and can do the gap analysis between their perceptions and expectations of the garments workers.

\section{References}

Ahmed, N., \& Nathan, D. (2014). Improving wages and working conditions in the Bangladeshi Garments Sector: The role of horizontal and vertical relations, Capturing the Gains. [Online] Available:

http//www.captuingthegains.org/publications/working paper/wp_201440.htm

Ahmed, U., Nasima, M., \& Alam, N. (2013). Sociobusiness consideration of garment workers in Bangladesh: A Statistical Review. ABC Journal of Advanced Research, 2(2), 8-17.

Armstrong, M. (2010). Strategic Human Resource Management. (1st Ed.). London: Kogan Page Limited 
BGMEA (2017). RMG: The Mainstay of Bangladesh Economy. [Online] Available: http//www.bgmea.com.bd/home/page

BGMEA (2015). [Bangladeh Garments Manufacturers and Exporters Association]: Data Source Export Promotion Bureau. [Online] Available:

http//www.bgmea.com.bd/home /pages/Trade Information

Bhuiyan, I. (2013). Reasonable wages for workers to eliminate unrest in Bangladesh's Ready-made Garments (RMG) Sector, The Bangladesh research Development Working Paper Series, 17, 1-17. [Online] Available: http://www.bangladeshstudies.org/wps

Blumer, H. (2016). International communication in Bangladesh ready-made-garment factories. [Online] Available: http://www.springer.com/gp/book/9783658120825

Burns and Busch (2007). Marketing Research ( $5^{\text {th }}$ ed), New Delhi, India, Dorling Kindersley, Pearson Education, South Asia.

Cooper, D., \& Schindler, P (2003), Business research methods, $8^{\text {th }}$ edition, McGraw Hill/Irwin, New York, NY 10020

Dicker, L. (2003). Employee Relations. How to build strong relationships you're your employees, South Wind Production, Singapore, pp.7-13

Ferdous, S. (2015). Factors promoting work satisfaction of ready-made-garments workers in Bangladesh; an empirical analysis. Journal of Scientific Research and Development, 2(8), 39-47.

ILO (2016). Improving working conditions in the ready-made-garment industry; progress and achievement. [Online] Available: http://www.ILO.org/dhaka/.whatwedo/projects/WCMs

ILO (2013). Improving Working Conditions in the Ready-Made Garment Sector in Bangladesh (RMGP Programme). [Online] Available:

http://www.ilo.org/dhaka/Whatwedo/Projects/safer-garment-industry-in...en/index.htm

Maslow, A. H. (1943). A theory of Human Motivation: Psychological Review, July, 370-396. https://doi.org/10.1037/h0054346

Mathis, R. L., \& Jackson, J. H. (2011). Human Resource Management. 13th ed. USA: South-Western Cengage Learning

Mohiuddin, M. (2014). Labor Management Relations Following the Labor Laws of Ready Made Garments in Bangladesh: The Present Perspective. IOSR Journal of Business and Management, 16(3), 32-36. https://doi.org/10.9790/487X-16343236

Montinaro, M., \& Chirico, P. (2006). Customer satisfaction measurement procedures; one dimensional and multi-dimensional approach. Statistical Applicator, 18(2), 277-296.

Nunally, J. (1978). Psychometric theory, New York, NY, McGraw-Hil.

Odhong, E., \& Omolo, J. (2014). An analysis of the factors affecting employee relations in the Flower Industry in Keneya, a case of Waridi Ltd, Athi River. International Journal of 
Business and Social Sciences, 5(11).

Oliver, L. (1980). A cognitive model of antecedents and consequences of satisfaction decisions. Journal of Marketing Research, 17(4), 460-469.

https://doi.org/10.1177/002224378001700405

Sekeran, U. (1992). Research methods for business, a skill building approach, second edition. John Wile and Sons, Inc, Canada.

The New York Times, (2012). Factory fire in Bangladesh. [Online] Available:

http://www.nytimes.com

Thomson, P. (2011). The trouble with HRM. Human Resource Management Journal, 21(14), 355-67. https://doi.org/10.1111/j.1748-8583.2011.00180.x

Westbrook, A. (1980). Interpersonal affective influences on consumer satisfaction with product. Journal of Consumer Research, 7, 49-54. https://doi.org/10.1086/208792

Wilkinson, A. (1999). Employment Relations in SMEs, Employee Relations, MCB University Press, 21(3), 206-217.

\section{Copyright Disclaimer}

Copyright for this article is retained by the author(s), with first publication rights granted to the journal.

This is an open-access article distributed under the terms and conditions of the Creative Commons Attribution license (http://creativecommons.org/licenses/by/3.0/). 